\title{
CZY WSZECHŚWIAT JEST DETERMINISTYCZNY?
}

\section{Problem}

Zagadnienie sięga greckiej tragedii. Fatum rządzi ludźmi i ich czynami, ale ludzie i ich czyny są częściami kosmicznego porządku. Swiat biegnie swoim torem. Bieg ten wciąga w swoje tryby losy jednostek $\mathrm{i}$ - jeżeli takie jest przeznaczenie - zgniata je bezlitośnie. Nawet bogowie nie są wyjęci spod władzy przeznaczenia. Greckie pojęcie fatum niewątpliwie należy umieścić u początków nowożytnego pojęcia prawa przyrody ${ }^{1}$.

Z czasem chrześcijańska doktryna o wolności woli, a potem moda na antropocentryzm i „filozofię wolności” zrobiły wyłom w sztywnym determinizmie odziedziczonym po Grekach: fatum, już przeobrażone w prawa fizyki, nadal rządzi światem, ale nie wykonuje już tak bezwzględnej władzy nad człowiekiem. Ludzkie dramaty stały się jeszcze bardziej dramatyczne, gdyż „wykroczyły poza świat martwej przyrody".

Wszelkie próby połączenia mechanistycznego determinizmu z „wyjątkowością" człowieka kończyły się prawie zawsze zabawnymi lamigłówkami. $\mathrm{Na}$ przykład: ktoś podczas górskiej wycieczki kopie kamień i wywołuje lawinę. Jak to możliwe, by w świecie, w którym wszystko - aż do najmniejszych poruszeń atomów - zostało zaprogramowane w warunkach początkowych (zadanych zresztą w dowolnej chwili), powstał nowy ciąg fizycznych przyczyn i skutków, spowodowany ruchem nogi człowieka, o którym to ruchu niczego nie wiedziały warunki początkowe? Nic więc dziwnego, że wielu myślicieli wolało raczej zrezygnować z wolności człowieka niż naruszyć porządek mechanistycznego świata. Dopiero powstanie mechaniki kwantowej stworzyło sprzyjający kontekst ideologiczny dla ludzkiej wolności. Jeżeli relacje Heisenberga indeterministycznie rządzą światem cząstek elementarnych, to dlaczego człowiek miałby być niewolnikiem mechaniki klasycznej?

Powstanie mechaniki kwantowej rzuca niewątpliwie nowe światło na zagadnienie kosmicznej ewolucji i jej zdeterminowania lub niezdeterminowania.

${ }^{1}$ Por. A. N. Whit ehe ad, Adventures of Ideas, New York 1967. 
Co więcej, zagadnienie to nie może być w pełni zrozumiane (ani nawet poprawnie postawione) zanim powstanie wiarygodna kosmologia kwantowa. Obecnie jednak - jak wiadomo - nie wyszła ona jeszcze poza etap mniej lub bardziej udanych prób; przyszłych rozwiązań można się jedynie domyślać. Dlatego też w niniejszym studium całkowicie pominę kwantowe aspekty problemu determinizmu lub indeterminizmu w kosmologii; zagadnienie będzie traktowane wyłącznie klasycznie i relatywistycznie. Jest to silne ograniczenie perspektywy. Musi mu towarzyszyć świadomość tymczasowości rozważań. A i tak rozważania okażą się doniosłe, ukazując, jak wiele mitów na temat klasycznego determinizmu nadal pokutuje w filozoficznej literaturze.

\section{Niektóre pojęcia i zagadnienia}

Omawiając temat o tak bogatej filozoficznej przeszłości, nie sposób nie poświęcić nieco uwagi pojęciowym rozgałęzieniom determinizmu. Należy wszakże usilnie wystrzegać się nadmiernego rozbudowywania analiz znaczeniowych, gdyż grożą one utopieniem interesujących zagadnień w werbalnych rozstrząsaniach. Niestety jest to częsty grzech filozofów zajmujących się problemem determinizmu i indeterminizmu. Ograniczymy się zatem do niezbędnych rozróżnień.

Popper na pierwszych stronach Otwartego wszechświata ${ }^{2}$ rozróżnia: (A) determinizm religijny, związany z wszechmocą i wszechwiedzą Boga (choć istnieją również i indeterministyczne interpretacje religii); greckie fatum ma w sobie coś z akcentów religijnych. (B) Determinizm naukowy, w którym rolę Boga przejęły na siebie prawa lub teorie naukowe. Tego rodzaju determinizm bardzo często przybiera postać „schematu przewidywania”: zdeterminowanie zdarzeń lub procesów oznacza możliwość ich przewidywania na podstawie znajomości „stanu układu” w pewnej chwili. (C) Determinizm metafizyczny, głoszący, że „bieg świata” jest ustalony raz na zawsze (prezdeterminowany), choć nikt nie musi ani znać „warunków początkowych” lub „obecnego stanu”, ani aktualnie przewidywać przyszły bieg wydarzeń.

Schemat przewidywania można również nazwać determinizmem epistemologicznym, gdyż idzie w nim nie tyle o zdeterminowanie samego „biegu świata", ile raczej o możliwość jego poznania (przewidywania). Rozważając determinizm ontologiczny - gdy bierze się pod uwagę nie przewidywania, lecz deterministyczny związek pomiędzy zdarzeniami (lub stanami świata) - można pytać o naturę tego związku³ ${ }^{3}$. Bardzo często milcząco (a niekiedy wyraźnie) zakłada się, że jest to związek przyczynowy, niekiedy jednak „upatruje się

\footnotetext{
${ }^{2}$ K. Poppe r, The Open Universe, Totowa 1982, roz. 1.

${ }^{3}$ Por. Z. A ugust ynek, Determinizm fizyczny, [w:] S. Amsterdamski, Z. Augustynek, W. Me j b a u m, Prawo-koniecznosć-prawdopodobienstwo, Warszawa 1964, s. 150.
} 
w determinacji pewien swoisty, odmienny od przyczynowego, stosunek między stanami, posiadający zresztą podłoże kazualne"4.

Innym bardzo interesującym zagadnieniem związanym $\mathrm{z}$ determinizmem jest problem zwrotu relacji zdeterminowania i jego stosunku do zwrotu czasu („strzałki czasu”) ${ }^{5}$. Schemat przewidywania w mechanice klasycznej działa w obie strony (istnieje symetria między predykcją i retrodykcją), ale pytanie dotyczy zwrotu relacji zdeterminowania w przebiegu rzeczywistych procesów fizycznych. Nie jest wcale sprawą oczywistą, że zwrot ten musi być zgodny ze strzałką czasu. Na przykład istnienie przyspieszonych (advanced) rozwiązań równań Maxwella świadczy o tym, że — przynajmniej z teoretycznego punktu widzenia - „wsteczne zdeterminowanie” procesów fizycznych związanych $\mathrm{z}$ promieniowaniem nie jest wykluczone.

\section{Uwagi o determinizmie klasycznym}

Nie wdając się w terminologiczne niuanse (jak to, wbrew swoim zasadom, czyni Popper w The Open Universe), przez determinizm klasyczny będę tu rozumieć determinizm funkcjonujący w fizyce (zwłaszcza mechanice) klasycznej. Mimo iż był on przedmiotem wielu studiów, w literaturze filozoficznej panuje wiele niedomówień, a nawet nieporozumień, na jego temat. Następujące uwagi mają na celu uchronić Czytelnika przed przynajmniej niektórymi z nich.

Przede wszystkim determinizm w fizyce klasycznej wygodnie jest dyskutować, posługując się językiem czasoprzestrzeni, a nie odrębnie czasu i przestrzeni, jak się to przeważnie czyni w publikacjach filozoficznych. W przypadku mechaniki klasycznej będzie to czasoprzestrzeń Galileusza ${ }^{6}$. Historia cząstki lub obserwatora jest krzywą w czasoprzestrzeni, ale nie każda krzywa może przedstawiać jakąś historię cząstki lub obserwatora. Krzywa, która może być historią, musi spełniać następujące warunki: (a) krzywa taka winna dać się sparametryzować przy pomocy monotonicznie rosnącego parametru; (b) winna być ciągła i przynajmniej dwukrotnie różniczkowalna. Parametr, monotonicznie rosnący wzdłuż krzywej, interpretuje się jako czas. Warunek (a) wyklucza więc cofanie się historii w czasie (rys. 1a) i ruchy z prędkością pozaczasową", tzn. z prędkością nieskończoną, dzięki której cząstka mogłaby znajdować się równocześnie w. kilku miejscach (rys. 1b).

\footnotetext{
4 Tamże, s. 151.

5 Por. tamże, s. 153.

${ }^{6}$ Por. np. W. Kopczyński, A. Trautman, Czasoprzestrzeń i grawitacja, Warszawa 1981, s. 36 - 56; D. J. Ra in e, M. Helle r, The Science of Space-Time, Tucson 1981, s. 57-81.
} 
a)

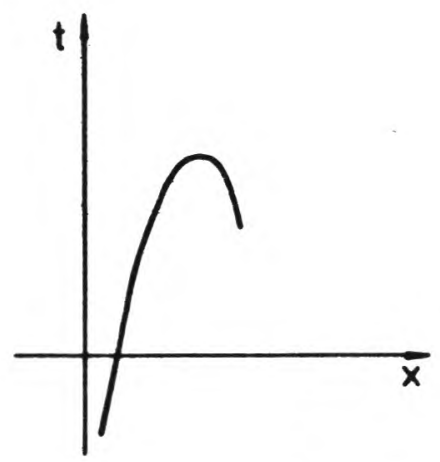

b)

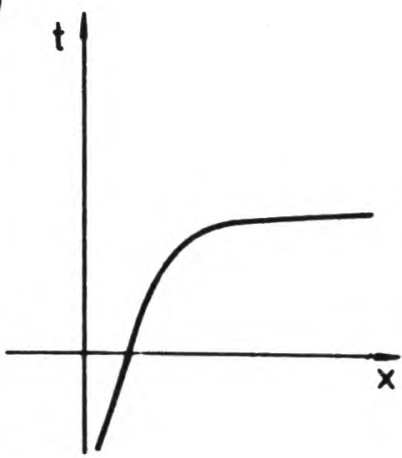

Rys. 1. Krzywe łamiące warunek (a).

Warunek (b)wyklucza sytuacje, w których cząstka mogłaby zniknąć w jednym miejscu i pojawić się w innym miejscu (złamanie ciągłości, rys. 2a) i sytuacje, w których cząstka nie posiadałaby jednoznacznie określonej prędkości (złamanie różniczkowalności, rys. 2b: na „szpicu” nie istnieje jednoznacznie określony wektor prędkości, styczny do krzywej).
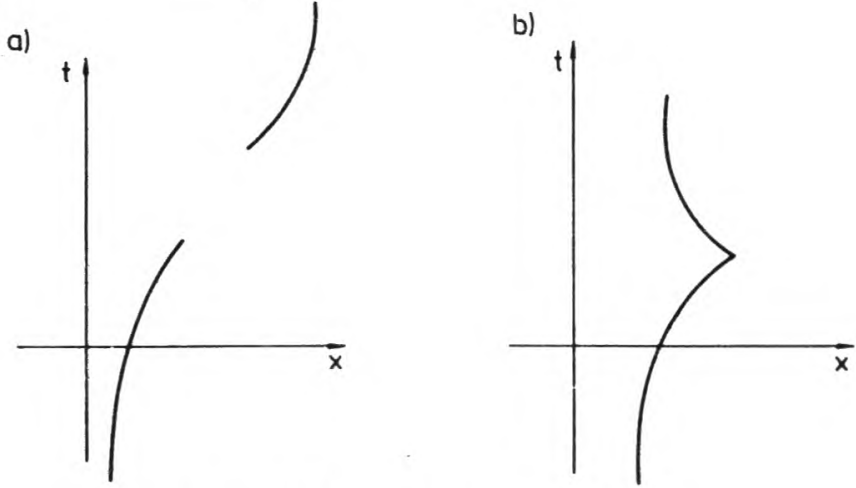

Rys. 2. Krzywe lamiące warunek (b)

Zbiór krzywych, spełniających powyższe warunki nazywa się zbiorem kinematycznie dopuszczalnych historii ${ }^{7}$. J. J. Sławianowski, komentując istnienie tego zbioru, pisze: „Zbiór nierzeczywistych, ale dających się wyobrazić sytuacji, jest koniecznym narzędziem przy badaniu i tłumaczeniu tego, co dzieje się naprawdę. Wyobrażenie o tym zbiorze zdobywamy przez wyabstrahowanie z posiadanego materiału doświadczalnego. Decydujące jest tu jednak subiektywne poczucie wolności: jeśli chcemy, możemy sprowokować — na jawie lub

${ }^{7}$ Obszerniej por. np. J. J. Sławia nowski, Geometria przestrzeni fazowych, Warszawa 1975, zwłaszcza s. 17 - 19. Popularnym wprowadzeniem do tych zagadnień jest pierwszy rozdzial książki tegoż autora: Przyczynowość w mechanice kwantowej, Warszawa 1969. 
w wyobraźni - sytuacje, które aktualnie nie mają miejsca" ${ }^{8}$. Zdaniem tego autora, „konieczność opisywania rzeczywistości przez zbiór nierzeczywistych, potencjalnych wydarzeń, jest wszystkim, co w jakimś stopniu daje się utrzymać z poglądów Kanta o istnieniu apriorycznych form poznania i oglądu" prowokujących uwag nie należy rozumieć w sensie absolutnym, lecz względnym, to znaczy nie w sensie jakoby każde ludzkie poznanie wymagało takiego a priori, lecz tylko w takim znaczeniu, że jeżeli zdecydujemy się stosować metody współczesnej matematyki, to musimy stosować wszystkie założenia tej metody, a wśród nich również założenie stwierdzające, że badane zjawisko fizyczne zawsze winniśmy umieścić w kontekście innych możliwych (kinematycznie dopuszczalnych) zjawisk ${ }^{10}$.

Jeżeli świat traktować jako „ograniczenie wszystkich możliwości”, to warunki, wybierające historie kinematycznie możliwe spośród wszystkich możliwych historii, należy uznać za pierwsze (zapewne najbardziej podstawowe) tego rodzaju ograniczenie. Drugim są prawa dynamiki, które spośród wszystkich kinematycznie dopuszczalnych historii wybierają tylko te, które spełniają prawa dynamiki danej teorii, w rozważanym przez nas przypadku — dynamiki Newtona. Historie takie będziemy nazywać dynamicznie dopuszczalnymi. Jak wiadomo, równania ruchu Newtona są równaniami różniczkowymi drugiego rzędu. Już sam ten fakt, nawet bez wnikania w konkretny kształt równań, niesie ważne informacje ${ }^{11}$. Okazuje się mianowicie, że — jeżeli dla uproszczenia

a)

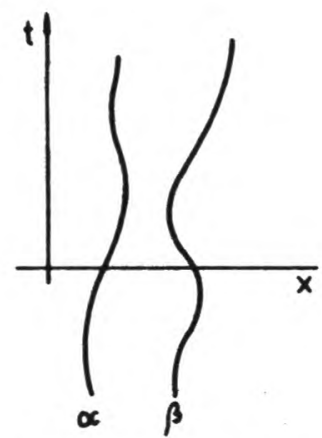

b)

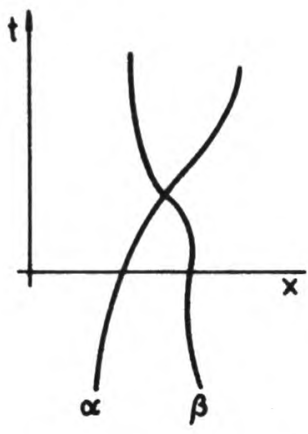

c)

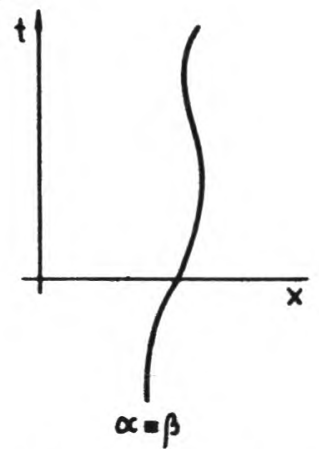

Rys. 3. Dwie historie punktu materialnego albo (a) są rozłączne, albo (b) mają jedno zdarzenie wspólne, albo (c) pokrywają się.

8 J. J. Sławi a nowski, Geometria..., s. 17.

${ }^{9}$ Tamże.

10 „Nauka szuka praw; dlatego też zajmuje się ona pilnie poszukiwaniem ograniczeń różnorodności. Tutaj większy zbiór składa się z tego, co mogloby się zdarzyć, gdyby zachowanie się było całkowicie dowolne i chaotyczne, mniejszy zbiór zaś z tego, co jest obserwowane w rzeczywistości" (W. Ros s A s h by, Wstep do cybernetyki, Warszawa 1963, s. 187).

${ }^{11}$ Analizę poniższą przedstawiam za J. J. Sła wi a now ski m: Przyczynowość..., s. $15 \mathrm{nn}$. 
rozważymy ruch jednego punktu materialnego - dwie różne dynamicznie dopuszczalne historie mogą mieć co najwyżej jedno zdarzenie (jeden punkt na wykresie) wspólne. Oczywiście mogą one nie mieć żadnego zdarzenia wspólnego, ale jeżeli mają dwa zdarzenia wspólne, to znaczy, że pokrywają się (por. rys. 3).

Innymi słowy: dwa zdarzenia jednoznacznie określają historię punktu materialnego. I na tym właśnie polega klasyczny determinizm. Znajomość dwu zdarzeń na historii jest pod tym względem równoważna znajomości jednego zdarzenia na historii i wektora stycznego w tym zdarzeniu do danej historii (rys. 4).

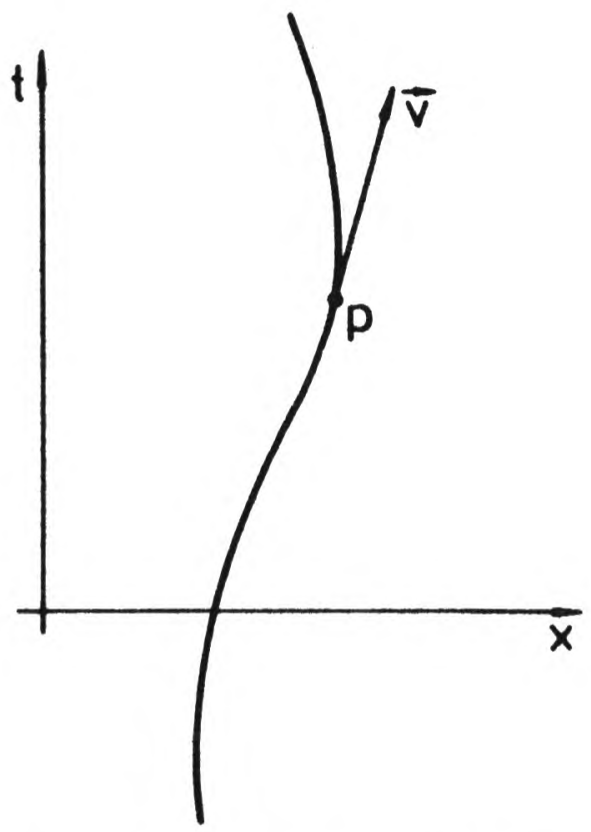

Rys. 4. Położenie punktu materialnego p w pewnej chwili i jego prędkość v w tej chwili jednoznacznie określają całą historię tego punktu. 
Zdarzenie odpowiada oczywiście położeniu punktu materialnego w danej chwili, a wektor styczny prędkości, jaką ten punkt posiada w danej chwili12. W każdym razie do jednoznacznego określenia historii nie wystarczy znajomość położenia punktu, należy znać również przynajmniej „infinitezymalne otoczenie" jednego punktu (czyli również prędkość w danej chwili), w przeciwnym razie ruch pozostanie niezdeterminowany. W potocznie używanym sformułowaniu „obecny stan ruchu jednoznacznie określa całą przeszłość i przyszłość" albo „obecny stan” należy rozumieć dostatecznie szeroko tak, by obejmował on ,infinitezymalne otoczenie” punktu, albo powiedzenie to jest nieprawdziwe w odniesieniu do mechaniki klasycznej.

Analiza powyższa jest również pod innym względem zaskoczeniem dla potocznych intuicji dotyczących determinizmu. Bardzo często bowiem uważa się, że cała przeszłość determinuje przyszłość, a tymczasem w mechanice klasycznej do zdeterminowania przyszłości potrzeba i wystarcza znajomość dwu punktów na historii poruszającej się cząstki.

Należy mocno podkreślić, że to, co zostało wyżej powiedziane, nie jest żadną „metafizyczną koniecznością" związaną z ,naturą determinizmu”, lecz jedynie następstwem własności równań, określających dynamicznie dopuszczalne historie w mechanice klasycznej. Znane są teorie fizyczne, posługujące się innego rodzaju równaniami, w których obowiązuje determinizm odmiennego typu. Tak na przykład równania elektrodynamiki Maxwella są równaniami różniczkowymi pierwszego rzędu. W przypadku swobodnego pola elektromagnetycznego historię układu (pola) jednoznacznie określa znajomość dwu funkcji wektorowych (odpowiadających sześciu funkcjom skalarnym), a mianowicie: natężenia pola elektrycznego $\mathrm{E}$ i natężenia pola magnetycznego $\mathrm{H}$ w całej przestrzeni w pewnej chwili. Intuicyjnie odpowiada to „stanowi układu w danej chwili". A zatem w klasycznej elektrodynamice bardziej dosłownie niż w klasycznej mechanice obowiązuje formuła: znajomość stanu układu w jednej chwili jednoznacznie determinuje całą historię układu.

Warto wspomnieć, że teoretycznie są możliwe - aczkolwiek dotychczas nie znalazły większego zastosowania w fizyce — „układy z pamięcią”, w których cała przeszłość determinowałaby przyszłą historię, lub „układy z celowością", w których przyszłość determinowałaby całą wiodącą ku niej historię. $\mathrm{W}$ takich układach mielibyśmy do czynienia $\mathrm{z}$ asymetrią przeszłość-przyszlość. Asymetria ta od samego początku byłaby wbudowana do praw danej teorii. Fakt, że mechanika newtonowska tego rodzaju asymetrii nie posiada, jest odpowiedzialny za brak w niej strzałki czasu.

Wszystko to świadczy o tym, że nie ma jakiegoś jednego determinizmu,

12 Należy wszakże zwrócić uwagę na fakt, że określenie historii przez podanie dwu różnych zdarzeń jest, w pewnym sensie, bardziej ogólne od określenia historii przez położenie i prędkość początkową; np. w przypadku nieróżniczkowalnej historii (np. procesu stochastycznego) pojęcie wektora stycznego może w ogóle być pozbawione sensu. 
który wynikałby „z natury rzeczy”; istnieje wiele postaci determinizmu w zależności od charakteru równań, przy pomocy których dana teoria fizyczna opisuje badany układ.

\section{Determinizm a przewidywalność. Chaos deterministyczny}

W swojej generalnej rozprawie $\mathrm{z}$ determinizmem Popper najpierw starannie określił , co rozumie przez „determinizm naukowy”, a następnie przytoczył racje, przemawiające za tym, że determinizm taki jest nie do utrzymania ${ }^{13}$. I tak - zdaniem Poppera - determinizm naukowy zawiera w sobie następujące twierdzenia: (a) stan dowolnego zamkniętego układu fizycznego w dowolnej przyszłej chwili może być przewidziany (b) nawet przez obserwatora, który jest częścią układu, (c) drogą dedukcji przy pomocy odpowiednich teorii naukowych, (d) z warunków początkowych, (e) które mogą być znane ze z góry zadaną dokładnością, wystarczającą do wykonania konkretnej predykcji. Określenie to punktami (b) i (e) różni się od standardowych "definicji” determinizmu. Punkt (b) wyklucza sytuację, w której przyszłość jest przewidywana przez superinteligentną istotę, znajdującą się w jakiś cudowny sposób „ponad” układem (która, na przykład, może w jednej chwili ogarnąć wszystkie zdarzenia równoczesne we Wszechświecie). A więc jeśli w determinizmie, rozumianym po popperowsku, można mówić o demonie Laplace'e, to musi to być demon podległy wszystkim prawom fizyki i zbierający informacje o układzie wyłącznie przy pomocy fizycznie dostępnych środków. Punkt (e) oznacza, mówiąc z grubsza, pewien realizm poznawczy obserwatora. Obserwator nie może znać danych początkowych „absolutnie dokładnie”, lecz zawsze z pewnym błędem, choćby to był błąd dowolnie mały (nie można wykluczyć postępu technicznego demona; ponieważ nie rozważamy tu efektów kwantowych, nie można nakładać a priori żadnego ograniczenia na ten postęp).

Popper twierdzi, że tak rozumiany determinizm jest nie do utrzymania, gdyż: po pierwsze, nawet gdyby teorie fizyki klasycznej istotnie sankcjonowały warunki (a) - (e), to i tak dotychczas nikt nie udowodnil, że wszystkie zjawiska we Wszechświecie są opisywane przy pomocy tych teorii (fizyka współczesna dowodzi czegoś wręcz przeciwnego) i po drugie, fizyka klasyczna nie spełnia wszystkich warunków (a) - (e). Celem uzasadnienia tego ostatniego stwierdzenia Popper powołuje się na pracę J. Hadamarda z 1898 r. ${ }^{14} \mathrm{~W}$ pracy tej Hadamard rozważa klasyczny ruch punktu ze stałą prędkością po geodetykach na gładkiej powierzchni o ujemnej krzywiznie i pokazuje, że znajomość warunków początkowych $\mathrm{z}$ absolutną dokładnością pozwala jednoznacznie przewi-

${ }^{13}$ K. Popper, The Open Universe, s. $29-40$.

${ }^{14}$ Les surfaces a courbures opposées [...], „Journal des Mathematiques Pures et Appliquées”, 4 (ser. 5): 1898 s. $27-73$. 
dywać ruch punktu, ale jakakolwiek nieoznaczoność danych początkowych, choćby dowolnie mała, po pewnym czasie czyni ruch całkowicie nieprzewidywalnym. A zatem w mechanice klasycznej nie spełniony jest warunek (e) popperowskiego określenia determinizmu naukowego ${ }^{15}$.

Argumentacja Poppera jest całkowicie poprawna. Trzeba przyznać, że powołując się na pracę Hadamarda (Popper czynił to już w latach pięćdziesią$\operatorname{tych}^{16}$ ), Popper wykazał duże wyczucie doniosłości zagadnień fizycznych. Nie tyle jednak artykuł Hadamarda z 1898 r. (który istotnie okazał się pracą pionierską), ile nieco tylko późniejsze prace Poincarégo (1903), po kilkudziesięciu latach niepełnego docenienia, zostały ponownie odkryte i rozwinięte (w latach siedemdziesiątych) do postaci zupełnie nowego stylu myślenia w matematyce. Zastosowanie nowych metod do fizyki przyczyniło się do tak daleko idących zmian w naszym rozumieniu świata, że — zdaniem Prigogine'a — jesteśmy dziś u progu jednej z najbardziej radykalnych rewolucji, jakie od czasów Newtona miały miejsce w nauce ${ }^{17}$. Powstały nowe czasopisma naukowe i nowe działy w dotychczas istniejących czasopismach, które zajmują się wyłącznie tą problematyką. Jest to dziś jedna $\mathrm{z}$ tzw. wiodących linii badań w fizyce ${ }^{18}$.

Zastosowanie nowych metod matematycznych do mechaniki klasycznej zmusiło do całkowitej reinterpretacji niektórych jej działów, w szczególności tych, które są związane z determinizmem ${ }^{19}$. „Nowa fizyka”, jak się ją często nazywa, zmusiła również do staranniejszego niż dotychczas rozróżnienia pomiędzy determinizmem i przewidywalnością. W dawnym paradygmacie oba te pojęcia były używane niemal zamiennie; obecnie okazało się, że istnieją układy fizyczne w pełni deterministyczne (np. układy opisywane przez mechanikę klasyczną), których zachowanie jest faktycznie nieprzewidywalne. Układy takie często nazywa się chaotycznymi lub deterministycznie chaotycznymi.

U podłoża deterministycznego chaosu leżą całkowicie deterministyczne prawa fizyki. Absolutna (tzn. nie obarczona żadnym błędem) znajomość warunków początkowych pozwoliłaby na jednoznaczne przewidywanie zachowania się układu, ale nawet dowolnie mały błąd w znajomości danych początkowych taką przewidywalność niszczy całkowicie. Już Poincaré mówił o przyczynach, których „małe zadziałanie” powoduje „,wielkie skutki”. Układy z chaosem deterministycznym wiążą się więc ze swoistą niestabilnością. Mała fluktuacja powietrza może w każdej chwili zburzyć domek z kart. W układach chao-

15 Ściśle rzecz biorąc, dla dowolnej (ale określonej) chwili w przyszłości można dobrać taką dokładność znajomości danych początkowych, by przewidzieć zachowanie punktu w tej chwili, ale nie można przewidzieć zachowania się punktu dla wszystkich przyszłych chwil.

${ }^{16}$ Por. Przedmowa do The Open Universe, s. XI.

17 Por. I. Prigogine, I. S tengers, Order out of Chaos, London 1985. Pierwsza wersja tej książki (w języku francuskim) nosiła wymowny tytuł: La Nouvelle Alliance (Paris 1979).

${ }^{18}$ Nie można znaleźć usprawiedliwienia dla W. W. Bartley'a, redaktora The Open Universe, że nie poinformowal on o tym czytelnika w jakimś przypisie, poprzestając na zacytowaniu przez Poppera pracy Hadamarda z 1898 r.

${ }^{19}$ Por. np.: W. I. A r nold, Metody matematyczne mechaniki klasycznej, Warszawa 1981. 
tycznych brak stabilności ma miejsce nie w spoczynku, lecz w ruchu: w każdej chwili ruch jest atakowany przez fluktuacje pochodzące $\mathrm{z}$ otoczenia. I właśnie fluktuacje powodują, że początkowo mały błąd w znajomości warunków początkowych gwałtownie narasta, niszcząc możliwość przewidywania.

Nie jest też prawdą (jak często potocznie się utrzymuje), że powodem zjawisk chaotycznych musi być wielkie nagromadzenie i skomplikowanie procesów, tworzących chaos. Znane są układy chaotyczne, składające się zaledwie z kilku elementów. Źródło chaosu jest bardziej podstawowe niż, jak sądzono, „nakładanie się” wielkiej liczby składników, zbyt wielkiej, by móc je mieć wszystkie „w ewidencji”. Źródłem chaosu są w istocie same prawa dynamiki, a ściślej —ich matematyczna postać, dopuszczająca odpowiedni rodzaj niestabilności ${ }^{20}$.

Matematyczną teorią chaosu jest teoria układów dynamicznych - bardzo bogata i niezwykle bujnie rozwijająca się dziedzina badań matematycznych ${ }^{21}$. Wszystko wskazuje na to, że dopiero zbliżamy się do etapu nowego widzenia i rozumienia świata. Już dziś widzimy, że determinizm, nazwany przez Poppera naukowym, jest nie do utrzymania. Po prostu świat nie jest deterministyczny w tym sensie. Co więcej, brak w ten sposób rozumianego zdeterminowania nie jest jakąś „uboczną” cechą świata. Świat bez deterministycznego chaosu byłby światem bez stawania się, bez możliwości jakiejkolwiek ewolucji. Wiemy już dziś na pewno, że chaos deterministyczny jest warunkiem koniecznym procesów prowadzących do powstawania „nowych jakości”, to znaczy procesów, które mielibyśmy prawo nazwać twórczymi, z procesem ewolucji biologicznej włącznie ${ }^{22}$. „Przyroda potrafi wykorzystywać chaos w sposób konstruktywny. Przez wzmacnianie małych fluktuacji otwiera ona układom drogę do nowości" 23 .

\section{Deterministyczna struktura czasoprzestrzeni}

W literaturze filozoficznej dotyczącej kwestii determinizmu krąży wiele mitów i uproszczeń. W poprzednim paragrafie widzieliśmy, jak postępy w teorii „deterministycznego chaosu” zmieniły całą sytuację problemową. Podobna zmiana perspektywy dokonuje się po uwzględnieniu osiągnięć fizyki relatywistycznej. Jak wiadomo, obie teorie względności (zarówno szczególna, jak i ogólna teoria względności) należą do fizyki klasycznej w tym sensie, że przed-

${ }^{20} \mathrm{~W}$ problematykę chaosu doskonale wprowadza artykuł: J. P. Crutchfield, J. D. Far me r, N. H. Pa ck a rd, R. S. Sh aw, Chaos, „Scientific American”, $255: 1986 \mathrm{nr} 6$ s. 38 - 49.

${ }^{21}$ Por. np. W. Szl e $\mathrm{k}$, Wstęp do teorii gładkich uktadów dynamicznych, Warszawa 1982; S. Sm al e, The Mathematics of Time - Essays on Dynamical Systems, Economic Processes, and Related Topics, Heidelberg - N. York 1980; W. I. A r n old, Teoria równań różniczkowych, Warszawa 1983.

${ }_{22}$ Por. I. Prigogine, I. Stengers, jw.

${ }^{23}$ J. P. Crutchfield..., jw., s. 48. 
stawiają niekwantowy obraz świata. Mimo to, zagadnienie determinizmu przedstawia się całkowicie odmiennie w świecie relatywistycznym niż to miało miejsce w klasycznym świecie Newtona. Odpowiedzialność za to ponosi fakt istnienia granicznej prędkości rozchodzenia się sygnałów fizycznych. Pociąga to za sobą istotne ograniczenie rozprzestrzeniania się informacji o danych początkowych. Skutkiem tego niekoniecznie cała czasoprzestrzeń musi być poddana determinującemu wpływowi warunków początkowych. Ponieważ nie ulega dziś wątpliwości, że świat w dużej skali winien być opisywany nie po newtowsku, lecz relatywistycznie, warto temu zagadnieniu poświęcić nieco więcej uwagi. Zacznijmy od wprowadzenia kilku fundamentalnych pojęć.

Podobnie jak w poprzednich paragrafach, sceną naszych rozważań będzie czasoprzestrzeń, ale tym razem czasoprzestrzeń z wbudowaną od początku strukturą, odpowiedzialną za istnienie granicznej prędkości rozchodzenia się sygnałów fizycznych. Matematycznym modelem takiej czasoprzestrzeni jest para (M, g), gdzie M jest 4-wymiarową rozmaitością, a g — metryką Lorentza określoną na M. Po ścisłe definicje Czytelnik winien sięgnąć do odpowiedniej literatury ${ }^{24}$. Celem zrozumienia dalszych rozważań wystarczy zapamiętać, że M modeluje zbiór, którego elementy nazywają się zdarzeniami w czasoprzestrzeni, a g określa „odległość” pomiędzy zdarzeniami oraz sprawia, że sygnały fizyczne, otrzymywane przez dane zdarzenie p i emitowane przez nie, rozchodzą się wewnątrz stożka świetlnego zdarzenia p (rys. 5), a na samym stożku

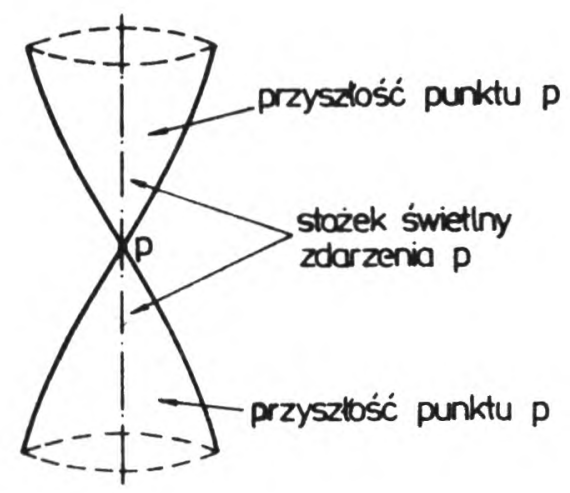

Rys. 5. „Stożkowa struktura” czasoprzestrzeni.

\footnotetext{
${ }^{24}$ Por. np. moje prace: The Manifold Model for Space-Time, „Acta Cosmologica” $10: 1981 \mathrm{~s}$. 33 - 50; Relativistic Model for Space-Time, tamże s. 53 - 69; lub w książce: Questions to the Universe, Tucson 1986.

${ }_{25}$ Popularne przedstawienie „stożkowej struktury czasoprzestrzeni” por. w mojej książce: Początek świata, Kraków 1976, roz. 3.
} 
rozchodzą się sygnały świetlne. Innymi słowy: krzywe w czasoprzestrzeni, które mogą być historiami fotonów (cząstek światła), zawsze leżą na stożku świetlnym i nazywają się krzywymi zerowymi lub świetlnymi; krzywe, które mogą być historiami sygnałów, rozchodzących się wolniej niż światło, leżą wewnątrz stożka świetlnego i nazywają się krzywymi czasopodobnymi; krzywe leżące, poza stożkiem świetlnym, nie mogą być historiami żadnych obiektów fizycznych i nazywają się krzywymi przestrzennopodobnymi ${ }^{25}$.

Niech $\mathrm{S} \neq \mathrm{O}$ będzie domkniętym, achronologicznym podobszarem czasoprzestrzeni. Wyjaśnijmy użyte tu określenia. Obszar czasoprzestrzeni nazywamy achronologicznym, jeżeli żadnych dwu punktów, leżących w tym obszarze, nie da się połączyć krzywą czasopodobną. Przyszłym obszarem zdeterminowanym przez S (lub przyszłym obszarem zależności od S) nazywamy zbiór takich punktów q należących do $\mathrm{M}$, że każda nieprzedłużalna w przeszłość krzywa czasopodobna, przechodząca przez q, przecina S. Przyszły obszar zdeterminowany przez $\mathrm{S}$ będziemy oznaczać przez $\mathrm{D}^{+}(\mathrm{S})$.

Kilka słów komentarza. Każda krzywa w czasoprzestrzeni rozciąga się w dwu kierunkach. Jeden z tych kierunków umawiamy się nazywać przyszłością, drugi - przeszłością. Umowa ta musi być tego rodzaju, by przyszłości i przeszłości określone dla wszystkich krzywych czasopodobnych były ze sobą zgodne. Teraz zrozumiałym staje się wyrażenie „krzywa skierowana w przeszłość”. Krzywą nazywamy przedłużalną, jeżeli ma ona punkt końcowy, to znaczy taki punkt, poza który zdecydowaliśmy się już dalej krzywej nie rysować, ale jeżeli zechcemy, to w każdej chwili możemy dorysować „dalszy ciąg” krzywej. Jeżeli tego nie da się zrobić, krzywą nazywamy nieprzedłużalną; na przykład wielkie koło na sferze jest krzywą nieprzedłużalną. Achronologiczny obszar S należy traktować jako „powierzchnię”, na której zadane są warunki początkowe dla pewnego (hiperbolicznego) równania różniczkowego (lub układu równań), rządzącego ewolucją świata (najczęściej są to równania Einsteina). Obszar $\mathrm{D}^{+}(\mathrm{S})$ reprezentuje tę część czasoprzestrzeni, do której równanie różniczkowe może przenieść - wzdłuż krzywych czasopodobnych - informacje o danych początkowych na S; w ten sposób dane te są w stanie zdeterminować zdarzenia zachodzące $w \mathrm{D}^{+}(\mathrm{S})$.

W zdeterminowanym świecie przewidywania można czynić zarówno w przód jak i wstecz w czasie. Zamieniając w powyższej definicji krzywe skierowane w przyszłość na krzywe skierowane w przeszłość, otrzymamy przeszły obszar zdeterminowany przez S (przeszły obszar zależności od S), który bę- 
dziemy oznaczać przez $\mathrm{D}^{-}(\mathrm{S})$. Łącznie $\mathrm{D}^{+}(\mathrm{S})$ i $\mathrm{D}^{-}(\mathrm{S})$ będziemy nazywać obszarem zdeterminowanym przez $\mathrm{S}$ (obszarem zależności od $\mathrm{S}$ ) i oznaczać przez $\mathrm{D}(\mathrm{S})$.

Jest teraz rzeczą oczywistą, że dane początkowe na $\mathrm{S}$ nie są w stanie zdeterminować obszarów czasoprzestrzeni leżących poza $\mathrm{D}(\mathrm{S})$. Okazuje się, że tylko w wyjątkowych wypadkach $\mathrm{M}=\mathrm{D}(\mathrm{S})$, tzn. cała czasoprzestrzeń jest równa obszarowi zdeterminowanemu przez S. Czasoprzestrzeń, dla której to zachodzi, nazywamy globalnie hiperboliczną. S nazywa się wtedy globalną powierzchnią Cauchy'ego. Jeżeli S jest globalną powierzchnią Cauchy'ego, to każda nieprzedłużalna krzywa czasopodobna przecina $\mathrm{S}$, a więc każde zdarzenie w czasoprzestrzeni globalnie hiperbolicznej może być zdeterminowane przez dane początkowe na S. Tylko w takich czasoprzestrzeniach może obowiązywać klasyczny determinizm typu tradycyjno-newtonowskiego.

Jeżeli $M \neq D(S)$, to powierzchnia odgraniczająca $D(S)$ od reszty czasoprzestrzeni nazywa się horyzontem Cauchy'ego; oznacza się ją przez H (S) (mówi się również o przyszłym i przeszłym horyzoncie Cauchy'ego, które oznacza się odpowiednio przez $\left.\mathrm{H}^{+}(\mathrm{S}) \mathrm{i} \mathrm{H}^{-}(\mathrm{S})\right)$. Horyzont Cauchy'ego $\mathrm{H}(\mathrm{S})$ oddziela więc te obszary w czasoprzestrzeni $\mathbf{M}$, które mogą być zdeterminowane przez dane początkowe na $S$ od tych, które nie mogą być zdeterminowane przez te dane ${ }^{26}$. Występowanie horyzontów Cauchy'ego w czasoprzestrzeni można traktować jako „miarę” załamywania się w niej determinizmu. Warto zauważyć, że przez każdy punkt, leżący na horyzoncie Cauchy'ego, przechodzi zerowa geodetyka; mówimy, że horyzont Cauchy'ego jest generowany przez te geodetyki.

Rozważmy prosty przykład. Niech $\mathrm{M}$ będzie czasoprzestrzenią Minkowskiego (tzn. czasoprzestrzenią szczególnej teorii względności). Czasoprzestrzeń ta jest globalnie hiperboliczna. Za globalną powierzchnię Cauchy'ego można wybrać na przykład każdą 3-wymiarową podprzestrzeń $\mathrm{t}=0$ (w zwyczajnych współrzędnych Minkowskiego). Ale po usunięciu jednego punktu (tylko jednego!) z czasoprzestrzeni Minkowskiego pojawia się w niej horyzont Cauchy'ego i, co za tym idzie, załamuje się jej struktura deterministyczna (por. rys. 6). Jest to doniosłe stwierdzenie. Nie daje ono wielkich szans światu, by był deterministyczny. Wystarczy, by zawierał on jedną czarną dziurę, prowadzącą do „klasycznej osobliwości”, by nie mógł on już być światem globalnie hiperbolicznym. Istotą argumentu jest to, że w klasycznych technikach (tzn. nie biorących pod uwagę kwantowych efektów grawitacji) osobliwości „dają znać” o sobie za pośrednictwem obszarów usuniętych z czasoprzestrzeni.

${ }^{26}$ Scisłą definicję horyzontu Cauchy'ego można znaleźć w: S. W. H a w k ing, G. F. R. Elli s, Large-Scale Structure of Space-Time, Cambridge 1973, s. 202 - 204. 


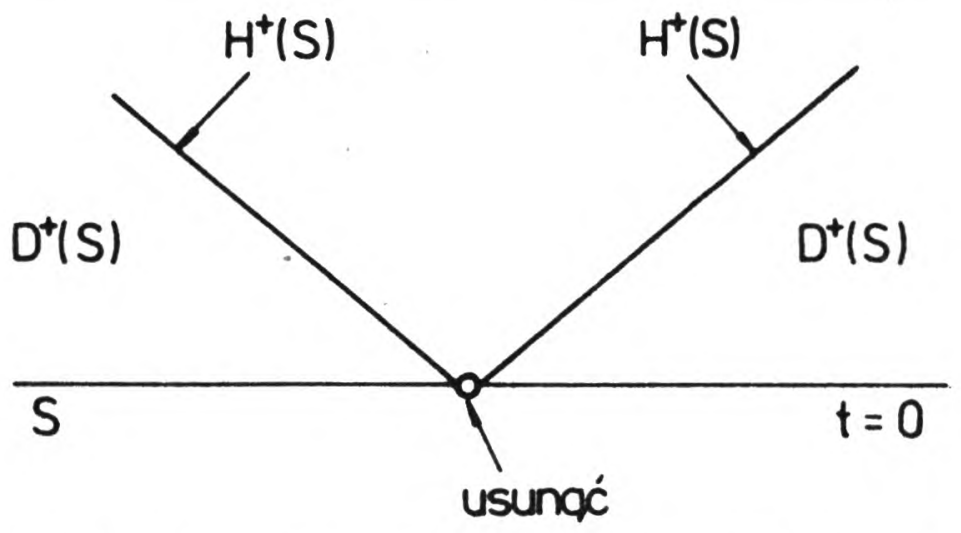

Rys. 6. Załamanie się struktury deterministycznej czasoprzestrzeni Minkowskiego po usunięciu $\mathrm{z}$ niej jednego punktu.

\section{Jeszcze jedna dygresja na temat Poppera}

Naszkicowana w poprzednim paragrafie „deterministyczna struktura czasoprzestrzeni" została przez fizyków-relatywistów znacznie rozbudowana i zastosowana do badania konkretnych problemów kosmologicznych (przede wszystkim do tzw. zagadnienia Cauchy'ego, bezpośrednio dotyczącego kwestii determinizmu, do problemu osobliwości w kosmologii i do innych zagadnień związanych $\mathrm{z}$ ewolucją młodego Wszechświata ${ }^{27}$ ). Przejrzysty język deterministycznej struktury czasoprzestrzeni pozwala jasno formułować pytania dotyczące determinizmu i w wielu wypadkach znajdować na nie odpowiedzi. Pragnę przytoczyć przykład trafnych intuicji filozoficznych, które doprowadziły do niepełnych wniosków tylko dlatego, że ich autor nie dysponował aparatem struktury deterministycznej.

W The Open Universe Popper poszukuje wszelkich możliwych argumentów przeciwko determinizmowi. Trzeba mu w tym przyznać wysoki stopień maestrii. Demon Laplace'a jest jednym z najbardziej maksymalistycznych wyrazów klasycznego determinizmu. Popper pragnie pokazać, że nawet demon Laplace'a, umieszczony w relatywistycznym świecie, musiałby zrezygnować z bardziej ambitnych przepowiedni dotyczących przyszłości ${ }^{28}$. W tym celu Popper umieszcza demona Laplace'a w czasoprzestrzeni Minkowskiego (a więc w świecie szczególnej teorii względności). Jak wiemy, czasoprzestrzeń ta jest globalnie hiperboliczna (Popper nie zna tego pojęcia). Argument Poppera

${ }^{27}$ Por. tamże.

${ }^{28}$ Por. The Open Universe, s. $60 \mathrm{nn}$. A więc - według terminologii Poppera - szczególna teoria względności nie jest teorią prima facie deterministyczną. 
sprowadza się do następującego rozumowania: Chcąc przewidzieć przyszłość świata, demon musi dysponować znajomością danych początkowych na całej globalnej powierzchni Cauchy'ego S (rys. 7).

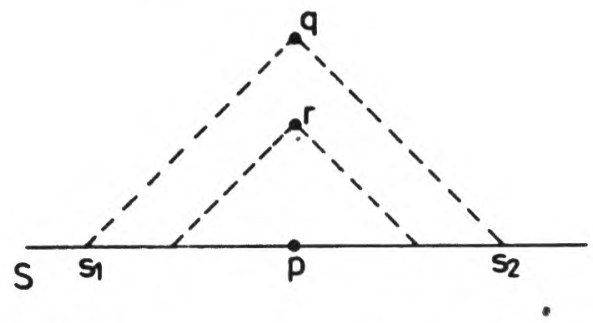

Rys. 7. Demon Laplace’a w czasoprzestrzeni Minkowskiego (według Poppera).

Gdyby demon umieścił się na powierzchni Cauchy'ego, na przykład w punkcie $p$, mógłby zebrać informacje o danych początkowych tylko ze swego bezpośredniego otoczenia. Pragnąc zebrać informacje o danych początkowych z większych obszarów powierzchni Cauchy'ego S, demon musi oddalić się od $\mathrm{S}$ w kierunku przyszłości. Ale niezależnie od tego, jak daleko oddaliłby się od $\mathrm{S}$, będzie w stanie zebrać informacje tylko z części powierzchni Cauchy'ego S. Na przykład, jeżeli demon umieści się w punkcie q, będzie mógł zgromadzić informacje jedynie z części powierzchni $S$ ograniczonej punktami $s_{1}$ i $s_{2}$. Wynika to oczywiście $\mathrm{z}$ istnienia granicznej prędkości przenoszenia informacji.

Popper zwraca uwagę na fakt, że demon, chcąc przewidzieć zdarzenie r na podstawie znajomości warunków początkowych na $S$, musi kontrolować te dane początkowe, które wpływają na zdarzenie $r$, a więc musi umieścić się w przyszłości zdarzenia r (tzn. „po" zdarzeniu r, na przykład w zdarzeniu q, rys. 7). A więc w szczególnej teorii względności ,realistycznie rozumiany” demon może wykonywać tylko retrodykcje (przewidywania wstecz), a nie predykcje.

Zrekonstruowany tu argument został przedstawiony przez Poppera w sposób opisowy i daleki od precyzji. Gdyby Popper znał język deterministycznej struktury czasoprzestrzeni i zastosował go do wyrażenia swoich intuicji, nie tylko zyskałyby one na ścisłości, ale całe rozumowanie mogłoby zostać uogólnione na szeroką klasę innych czasoprzestrzeni. Przyjrzyjmy się jeszcze raz całemu zagadnieniu.

Popper ma rację gdy twierdzi, że demon może zebrać informacje tylko z części powierzchni Cauchy'ego, ale tylko pod warunkiem, że demon będzie oddalony od tej powierzchni o skończoną „odległość” (mierzoną czasem własnym). Ale jeżeli demon zdecyduje się zająć pozycję w „czasowej plus nieskończoności”, odzyska swoją demoniczną wiedzę o świecie. Globalną strukturę przyczynową czasoprzestrzeni Minkowskiego (po odpowiednim przeskalowaniu konforemnym) przedstawia rys. 8 . 


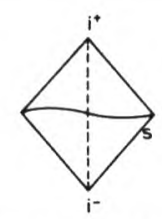

Rys. 8. Globalna struktura przyczynowa czasoprzestrzeni Minkowskiego

Punkt $\mathrm{i}^{+}$na tym rysunku reprezentuje „czasową plus nieskończoność”. Nazwa „czasowa plus nieskończoność” odzwierciedla fakt, że podróż obserwatora $\mathrm{z}$ powierzchni $\mathrm{S}$ do punktu $\mathrm{i}^{+}$musiałaby trwać nieskończenie długo (w jego czasie własnym). Analogicznie punkt $\mathrm{i}^{-}$przedstawia „czasową minus nieskończoność”. Rysunek 8 jasno pokazuje załamanie się argumentu Poppera, gdy demon znajduje się $\mathrm{w}$ punkcie $\mathrm{i}^{+29}$.

Warto wspomnieć, że właśnie tę możliwość wykorzystał F. J. Tipler, konstruując swój matematyczny model teilhardowskiego Punktu Omega ${ }^{30}$. Tipler rozważa czasoprzestrzenie o strukturze przyczynowej podobnej do struktury przyczynowej czasoprzestrzeni Minkowskiego. To właśnie punkt $\mathrm{i}^{+}$Tipler utożsamia z Punktem Omega, będącym, według niego, ostatecznym celem ewolucji Wszechświata. Motyw tego utożsamienia sprowadza się do tego, że istota inteligentna, znajdująca się $\mathrm{w}$ punkcie $\mathrm{i}^{+}$może znać całą przeszłość świata. W obserwatorze, znajdującym się w punkcie $\mathrm{i}^{+}$, Tipler dopatruje się Boga, będącego wytworem i celem ewolucji świata ${ }^{31}$. Nie chcę tu dokonywać oceny filozoficznej wizji Tiplera ${ }^{32}$, pragnę jedynie zwrócić uwagę na fakt, że opiera się ona na znacznie bardziej wyrafinowanych argumentach zaczerpniętych z teorii względności niż rozumowanie Poppera.

Popper mógłby jednak ograniczyć podróżnicze możliwości demona, zezwalając mu na przenoszenie się jedynie do skończenie odległych obszarów czasoprzestrzeni i w ten sposób bronić słuszności swojego argumentu. Okazuje się jednak, że argument Poppera można podważyć jeszcze całkiem inaczej. W teorii względności istnieje bowiem możliwość zadawania danych początkowych nie na achronologicznej powierzchni S, lecz na stożku świetlnym L (por. rys. 9). Wówczas demon unieszczony w punkcie q, zasadniczo bez żadnych kłopotów, może zebrać informacje o danych początkowych na L. Wystarczą one do

$29 \mathrm{Na}$ temat globalnej struktury przyczynowej czasoprzestrzeni Minkowskiego por.: S. W. Hawking, G. F. R. E1lis, jw., s. 118 - 124 lub bardziej popularnie: M. Helle r, Questions to the Universe..., s. $108-109$.

${ }^{30} \mathrm{~W}$ książce napisanej razem z J. D. B a r row e m: The Anthropic Cosmological Principle, Oxford 1986, roz. 10; por. także J. F. T i pl e r a, The Omega Point Theory: A Model of an Evolving God [w:] Physics, Philosophy and Theology. A Common Quest for Understanding, ed. R. J. R u ss el, G. V. Coyne, Vatican City State 1988, s. 313 - 331.

31 Tipler rozwija tę myśl w swoim odczycie na konferencji w Castel Gandolfo (por. przypis 30).

32 Por. moje uwagi krytyczne dotyczące książki Barrowa i Tiplera w recenzjach umieszczonych w: „Classical and Quantum Gravity” 3:1986 s. 727 - 728; "The Review of Metaphysics" March 1987 s. $564-565$. 
do „przewidywania” przeszłości świata, choć mogą wystąpić kłopoty z przewidywaniem jego przyszłości (jeżeli równania rządzące ewolucją świata są hiperboliczne, to nie da się ich całkować „na zewnątrz stożka”"33).

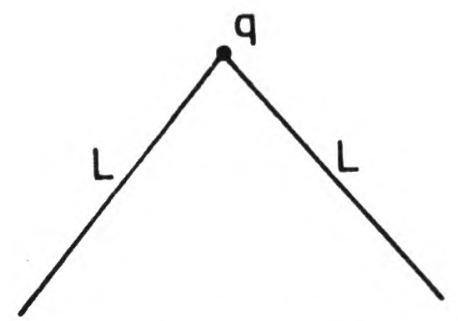

Rys. 9. Dane początkowe na stożku świetlnym.

Wykorzystując techniki badania deterministycznej struktury czasoprzestrzeni, można poszukiwać odpowiedzi na następujące ogólne pytanie: czy istnieją takie czasoprzestrzenie, w których przyszłość każdego obserwatora jest całkowicie zdeterminowana przez dane początkowe, które ten obserwator sam może przynajmniej w zasadzie - obserwować? Odpowiedź na to pytanie jest pozytywna. Czasoprzestrzenie spełniające to wymaganie nazywają się czasoprzestrzeniami deterministycznymi; zdefiniowali je i poddali badaniom R. Budic i P. K. Sachs ${ }^{34}$.

Wszystkie przytoczone powyżej analizy, przeprowadzone przy wykorzystaniu deterministycznej i przyczynowej struktury czasoprzestrzeni, potwierdzają filozoficzne intuicje Poppera. Gdyby Popper dysponował znajomością tych struktur, jego argumenty przeciwko klasycznemu determinizmowi byłyby bardziej wiarygodne i pełniej udokumentowane.

Przypadek Poppera zdarzył się również Romanowi Ingardenowi. Filozof ten wypowiedział wiele trafnych spostrzeżeń na temat przyczynowej zależności zdarzeń, niejako odkrywając jeszcze raz, niezależnie od teorii względności, przyczynową strukturę świata $^{35}$. Ponieważ jednak wszystkie jego analizy były przeprowadzone bez użycia matematyki, Ingarden nie wyszedł w zasadzie poza wnioski słuszne tylko w ramach szczególnej teorii względności i to tylko dla najprostszych sytuacji dopuszczalnych przez tę teorię.

${ }^{33}$ Por. G. F. R. Ellis, S. D. Nel, R. Maartens, W. R. Stoeger, A. P. Whitman, Ideal Observational Cosmology, „Physics Reports” $124: 1985$ s. $315-417$.

34 W pracy: Scalar Time Functions: Differentiability, [w:] Differential Geometry and Relativity (in Honour of A. Lichnerowich), ed. M. Cahen, M. Flato, Dordrecht-Boston, 1976, s. $215-224$.

${ }_{35}$ Por. $\mathrm{m}$. in.: R. Ing ard e n, Quelque remarques sur la relation de causalité, „Studia Philosophica" 3: $1939-1946$ s. $151-165$. 


\section{Uwagi na zakończenie}

Niniejsze studium nie wniosło zasadniczo niczego nowego. Mýślę, że na tym właśnie polega jego doniosłość. Przedstawiłem w nim sprawy, które są doskonale znane, i to od dość dawna, fizykom - specjalistom w zakresie zagadnień związanych z tzw. chaosem deterministycznym i teorii względności. Umieściłem całą tę problematykę $\mathrm{w}$ nie całkiem dla niej zwyczajnym kontekście, a mianowicie $w$ kontekście filozoficznych rozważań o determinizmie i indeterminizmie. Zabieg ten natychmiast ujawnil wiele mitów nadal obecnych w filozoficznych publikacjach. Przypadek Poppera nie jest całkiem typowy. Wprawdzie wiek nie pozwolił temu filozofowi nadążać za postępem fizyki, ale wnikliwość jego analiz sprawiła, że dokonal on wiele spostrzeżeń, które dla fizyków poprzedniego pokolenia mogłyby mieć charakter cennych wyników.

Deterministyczna wizja świata jest dziś nie do utrzymania, nawet gdy ograniczyć się tylko do fizyki klasycznej. Teoria deterministycznego chaosu, termodynamika nieliniowa i metody układów dynamicznych ujawniły nieprzewidywalny charakter fundamentalnych praw mechaniki klasycznej. Wprawdzie prawa te, ściśle rzecz biorąc, są nadal deterministyczne (przy założeniu nieskończenie dokładnej znajomości warunków początkowych), ale w wielu wypadkach odznaczają się one tym szczególnym rodzajem niestabilności, który niszczy wszelką realistycznie rozumianą przewidywalność (tzn. z zastrzeżeniem, że dane początkowe są znane $\mathrm{z}$ dowolną, ale skończoną, dokładnością). A przewidywalność taka była powszechnie uważana bądź za część składową, bądź nawet za synonim determinizmu.

Teoria względności należy do fizyki klasycznej (w swoich standardowych wersjach nie uwzględnia ona kwantowych efektów grawitacji). Teoria ta nakłada również istotne ograniczenia na determinizm. Istnienie granicznej prędkości rozprzestrzeniania się informacji sprawia, że tylko wyjątkowe czasoprzestrzenie (globalnie hiperboliczne) mogą być uważane za odpowiadające klasycznym wyobrażeniom o determinizmie. W innych czasoprzestrzeniach mogą pojawiać się horyzonty Cauchy'ego, ograniczające obszar zdeterminowany przez dane początkowe na powierzchni Cauchy'ego. Jak pamiętamy, usunięcie jednego punktu z globalnie hiperbolicznej czasoprzestrzeni pociąga za sobą wystąpienie horyzontów Cauchy'ego i załamanie się globalnego determinizmu.

Nie trzeba dodawać, że sukcesy mechaniki kwantowej i elektrodynamiki kwantowej dają silną podstawę przekonaniom o kwantowym $\mathrm{i}$ indeterministycznym charakterze fundamentalnych oddziaływań fizycznych. Ale jest to odrębny problem, zresztą znacznie bardziej obecny w literaturze filozoficznej niż omawiane w tym studium zagadnienie „klasycznego determinizmu”. Obydwa te problemy spotykają się w obecnych próbach stworzenia kwantowej teorii grawitacji czy kwantowej kosmologii. Dopiero z chwilą, gdy próby te zostaną 
uwieńczone sukcesem, będzie można poprawnie postawić, i być może rozwiązać, problem deterministycznego czy indeterministycznego charakteru świata.

\section{IS THE UNIVERSE DETERMINISTIC?}

\section{Summary}

The question asked in the title is considered within the framework of contemporary non-quantum physics. The phenomenon of the deterministic chaos and the deterministic structure of space-time (disclosed by general relativity) are taken into account. They impose strong limitations on the deterministic character of classical physics. It turns out that there is no determinism the nature of which could be a priori established, but the deterministic or indeterministic character of a given physical theory is encoded in its mathematical structure. Popper's views on the subject are critically reviewed. 